\title{
An abortion storm in dairy cattle associated with neosporosis in southern Brazil
}

\author{
Um surto de abortamento em vacas leiteiras associado com neosporose no \\ sul do Brasil
}

\begin{abstract}
João Henrique Perotta; Bárbara Barbi de Freitas²; Nicoly Nayana Marcom¹; Caroline Argenta Pescador³; Cláudia Carnielli Pereira4; Rosângela Locatelli-Dittrich'; Juliana Sperotto Brum¹; Ivan Roque de Barros Filho ${ }^{\text {* }}$ (D)

' Departamento de Medicina Veterinária, Setor de Ciências Agrárias, Universidade Federal do Paraná - UFPR, Curitiba, PR, Brasil ${ }_{2}^{2}$ Programa de Pós-graduação em Ciências Veterinárias, Departamento de Medicina Veterinária, Setor de Ciências Agrárias, Universidade Federal do Paraná - UFPR, Curitiba, PR, Brasil

${ }^{3}$ Departamento de Clínica Médica Veterinária, Faculdade de Medicina Veterinária, Universidade Federal do Mato Grosso - UFMT, Cuiabá, MT, Brasil

${ }^{4}$ Centro Diagnóstico Marcos Enrietti, Curitiba, PR, Brasil
\end{abstract}

\begin{abstract}
How to cite: Perotta JH, Freitas BB, Marcom NN, Pescador CA, Pereira CC, Locatelli-Dittrich R, et al. An abortion storm in dairy cattle associated with neosporosis in southern Brazil. Braz J Vet Parasito/ 2021; 30(2): e001821. https://doi.org/10.1590/S1984-
\end{abstract} 29612021045

\begin{abstract}
Between December 2016 and April 2017, a spate of abortions occurred in a closed dairy herd from the central eastern region of Paraná, Brazil, in which 75 cows aborted. To identify its cause, organ fragments were collected from an aborted fetus for histopathology, and the blood samples from a stillborn, 4 aborted fetuses, and 9 farm dogs for indirect fluorescent antibody technique (IFAT). These tests found multifocal non-suppurative encephalitis, periportal hepatitis, and multifocal lymphoplasmacytic myocarditis, and detected anti-Neospora antibodies in all aborted fetuses, and in 5 of the 9 dogs. DNA of Neospora caninum was detected in the brain tissue of an aborted fetus. Blood samples of 340 cows and 146 heifers showed $33.5 \%$ and $30.8 \%$ seropositivity, respectively. In this closed herd, the parasite was probably introduced by infected domesticated or wild carnivores inhabiting the farm, through the infective oocysts present in their stool.
\end{abstract}

Keywords: Dairy cattle, abortion, N. caninum, outbreak.

\begin{abstract}
Resumo
Um surto de abortamento com 75 abortos ocorreu em um rebanho fechado de vacas leiteiras da região centro Leste do Paraná entre dezembro e abril de 2017. Para chegar ao diagnóstico, fragmentos de órgãos foram coletados de um feto abortado e submetidos para histopatologia; e amostras de sangue foram coletadas de 1 natimorto, de 4 fetos abortados e de 9 cães da propriedade, para detecção de anticorpos pela reação de imunofluorescência indireta (RIFI). Foram encontradas encefalite multifocal não supurativa, hepatite periportal e miocardite linfoplasmocitária multifocal. Anticorpos anti-Neospora foram detectados em todos os fetos abortados e em 5 dos 9 cães. DNA de $N$. caninum foi detectado no tecido cerebral de um dos fetos abortados. Amostras sanguíneas de 340 vacas e 146 novilhas mostraram uma soropositividade para $N$. caninum de 33,5\% e 30,8\%, respectivamente. Nesse rebanho fechado, o parasita foi introduzido possivelmente pelas fezes de cães domésticos ou selvagens infectados que habitam a propriedade.
\end{abstract}

Palavras-chave: Vacas leiteiras, abortamento, N. caninum, surto. 


\section{Introduction}

Neospora caninum (Apicomplexa: Sarcocystidae) was first described as coccidia, present in the central nervous system and skeletal muscles of dogs with encephalomyelitis and myositis, respectively (Bjerkås, et al., 1984). Neosporosis, in turn, is considered as the largest cause of abortion in cattle in many countries (Almería \& LópezGatius, 2013), resulting in significant economic losses due to lost pregnancies, requirement of suitable facilities for safe disposal of infected carcasses, and reduced milk yield (Dubey et al., 2007; Pessoa et al., 2016). Weak calves born with low weight and neuromuscular disorders, and normal calves with persistent infection, add to the economic burden (Uesaka et al., 2018).

Approximately $20 \%$ of the abortions in dairy herds from Brazil are associated with neosporosis, and the consequent annual losses incurred by the Brazilian dairy cattle industry were estimated to be about US\$51.3 million (Reichel et al., 2013; Dubey et al., 2007). In Paraná State, seropositivity was reported in $14.3 \%$ to $34.8 \%$ of the dairy herds (Locatelli-Dittrich et al., 2001; Guimarães et al., 2004), and N. caninum was detected in $23.5 \%$ of the aborted fetuses (Santos et al., 2005).

Dogs and wild carnivores are the definitive hosts of N. caninum (McAllister et al., 1998; Gondim et al., 2004), and they are infected by the ingestion of bradyzoites present in tissues of the intermediate hosts, such as cattle. Oocysts are excreted in the feces of the definitive hosts, and the cattle become infected through the contaminated water and food (McAllister et al., 1998; Dubey et al., 2007; Lindsay et al., 1999). These resources may prove to be common source of infection, and any exposure to these, can lead to abortion storms in a naïve herd (McAllister et al., 1996).

Cattle infection with N. caninum might occur through different routes, including horizontal (ingestion of oocysts), exogenous transplacental (ingestion of oocysts by a pregnant cow), and endogenous transplacental (fetus infected by a latent infection reactivated in a pregnant cow) transmission (McAllister, 2016). The transmission of $N$. caninum through the transplacental route is the most efficient, as it causes endemic infections. The cycle of endogenous infection is persistent in the herd because the infected cow gives birth to an infected calf, which consequently enters the breeding herd and perpetuates the infection (McAllister, 2016).

Objective of this study was to report an outbreak of N. caninum induced abortions in a dairy farm in the Central Eastern mesoregion of Paraná State, Brazil, describing its epidemiological and clinical aspects, as well as the diagnostic methods.

\section{Material and Methods}

A high-yielding dairy farm (> 8,500 kg milk/305 days/cow) from the municipality of Arapoti ( $\left.24^{\circ} 09^{\prime} 28^{\prime \prime} \mathrm{S} 49^{\circ} 49^{\prime} 37^{\prime \prime} \mathrm{O}\right)$, Paraná State, from southern Brazil experienced a 5-month-long abortion storm between December 2016 and April 2017. The herd consisted of 498 Holstein dairy cattle, including 250 lactating cows, housed in a free-stall system. Cows were fed a mixed ration of corn silage, commercial feed, and Tifton grass hay. Corn silage and grass hay were produced in the farm.

The herd had been officially classified as tuberculosis- and brucellosis-free herd, and the animals had been vaccinated against infectious bovine rhinotracheitis (IBR), bovine viral diarrhea (BVD), leptospirosis, and foot-andmouth disease. Replacement animals were raised on the farm, and no heifers or cows had been purchased for more than 30 years. Dogs (Canis lupus familiaris) around the farm had access to the food storage sites, water troughs, and pasture areas. There were sighting of crab-eating foxes (Cerdoxcyon thous), and stray dogs in the premises of this farm. Practice of disposing the dead animals, aborted fetuses and fetal membranes in open, non-isolated places, was another risk factor.

Between December 2016 and March 2017, 75 cows and heifers suffered abortion. In December 2016, the farm's veterinarian collected blood samples from 14 cows among these, and got them tested at the Instituto Biológico de São Paulo for IBR/BVD, neosporosis and leptospirosis.

In March 2017, clinical and epidemiological data were collected from the farm, and a necropsy of an aborted fetus of about six-month-old pregnancy (fetus 1) was performed, but there were no significant findings. Sections of the liver, spleen, thymus, kidney, heart, skeletal muscle, lung, and central nervous system were collected and fixed in neutral-buffered $10 \%$ formalin. Blood samples from the heart and samples of peritoneal and pleural fluids were collected for serological analyses. Tissue samples were processed, embedded in paraffin, $4 \mu \mathrm{m}$-thick sections cut, and stained with hematoxylin and eosin (HE) for microscopy. While the necropsy of fetus 1 was in progress, 
a cow expelled a stillborn male calf. Necropsy of this was conducted immediately, and the blood samples were collected from the heart, for serology.

Between March and May 2017, three aborted fetuses (fetus No. 2-4) of approximately 6, 4, and 5 months of gestational age, respectively, were received at the College of Veterinary Medicine-Universidade Federal do Paraná for necropsy, which showed no macroscopic abnormalities. Blood samples taken from the heart were centrifuged, and the serum was stored at $-20^{\circ} \mathrm{C}$, for further analyses.

To identify the causative agent, DNA from $0.05 \mu \mathrm{g}$ of the brain tissue of the fetus 1 was extracted with phenol-chloroform and amplified with polymerase chain reaction (PCR). Nested-PCRs were conducted to identify N. caninum DNA, using following primers: NN1 (5'-TCAACCTTTGAATCCCAA-3), NN2 (5'-CGAGCCAAGACATCCATT-3 ${ }^{\prime}$ ), NP1 (5' -TACTACTCCCTGTGAGTTG-3'), and NP2 (5'-TCTCTTCCCTCAAACGCT-3). These yielded 213 base pair (bp) fragments of the ITS-1 (internal transcribed spacer) region of $N$. caninum rRNA.

Primary reaction was performed in a final volume of $25 \mu \mathrm{L}$ containing $10 \mathrm{ng}$ DNA, $1.5 \mathrm{mM} \mathrm{MgCl}{ }_{2}, 1 \times$ PCR buffer (200 mM Tris-HCl pH 8.4, $500 \mathrm{mM} \mathrm{KCl),} 0.2 \mathrm{mM}$ dNTPs, 10 pmol of each primer, and $1 \mathrm{U}$ of Taq DNA polymerase (Invitrogen, California, USA), in a MyCycler ${ }^{T M}$ thermalcycler (Bio-Rad Laboratories, Inc), with following conditions: initial denaturation at $94{ }^{\circ} \mathrm{C}$ for 4 min, followed by 26 cycles of 2 min at $94{ }^{\circ} \mathrm{C}$, annealing at $50{ }^{\circ} \mathrm{C}$ for 2 min, extension at $72{ }^{\circ} \mathrm{C}$ for $2 \mathrm{~min}$, and a final extension at $72{ }^{\circ} \mathrm{C}$ for 5 minutes. For the secondary reaction, $1 \mu \mathrm{L}$ of the primary amplification product was used, and PCR was carried out under the same conditions, with NN1 and NN2 primers. Ultrapure water was used as negative control, and previously identified N. caninum DNA served as positive control.

Due to the genetic proximity of $N$. caninum and $T$. gondii (Reid et al., 2012), PCR was conducted to detect the latter, using the universal primers described by Burg et al. (1989), which amplifies a species-specific 194 bp fragment of the $\mathrm{B} 1$ gene of $T$. gondii. Amplification reaction contained $10 \mathrm{pmol}$ of each primer, $2.7 \mathrm{mM} \mathrm{MgCl}, 1 \times \mathrm{PCR}_{2}$ buffer (200 mM Tris-HCl pH 8.4, 500 mM KCl), 0.2 mM dNTPs, 1 U Taq DNA polymerase (Invitrogen, California, USA), and $10 \mathrm{ng}$ DNA in a final volume of $25 \mu \mathrm{L}$. Reaction was carried out as follows: initial denaturation at $95^{\circ} \mathrm{C}$ for 5 min, 30 cycles of $30 \mathrm{~s}$ at $95^{\circ} \mathrm{C}$, annealing at $47^{\circ} \mathrm{C}$ for $45 \mathrm{~s}$, extension at $72^{\circ} \mathrm{C}$ for $2 \mathrm{~min}$, and a final extension at $72^{\circ} \mathrm{C}$ for $5 \mathrm{~min}$. Ultrapure water, and the genomic DNA extracted from the parasite were used as negative and positive control, respectively. All amplification products were stained with GelRed ${ }^{\top \mathrm{m}}$ (Nucleic Acid gel stain, Biotium Company, California, USA), electrophoresed on $2 \%$ agarose gels, and analyzed with ChemiDoc ${ }^{\top m}$ XRS + photodocumentation system and the ImageLab ${ }^{\text {TM }}$ software (both from Bio-Rad Laboratories, Inc). A 100 bp ladder (GeneRuler 100pb DNA Ladder, Thermo Fisher Scientific, Massachusetts, USA) was used as the molecular weight marker.

In April 2017, $2 \mathrm{~mL}$ of blood was taken from the jugular vein of nine dogs from the farm, and from the coccygeal vessels of 340 cows and 146 heifers. Blood samples were centrifuged at $1500 \mathrm{~g}$ for $5 \mathrm{~min}$, and the sera were collected and stored at $-80^{\circ} \mathrm{C}$ for analyses. Samples from the cows were also tested by direct ELISA (IDEXX BVDV $\mathrm{Ag} /$ Serum Plus Test ${ }^{\mathrm{TM}}$ ) for BVD virus (BVDV), to identify the persistently infected animals. Blood samples from cows and heifers were tested for anti-Neospora antibodies using an indirect ELISA test (IDEXX ${ }^{\mathrm{TM}}$ Kit Neospora X2 Ab Test Antibody Test).

Serum samples of the aborted fetuses, stillborn calf, and dogs were tested for anti-N. caninum IgG, through the indirect fluorescent antibody technique (IFAT). Slides were prepared with N. caninum tachyzoites (NC-1), harvested from cell culture (Locatelli-Dittrich et al., 2006). Dog sera were diluted 1:50, while those from the fetuses were used undiluted. Positive and negative controls were included. The bovine anti-IgG conjugate (Sigma Aldrich, São Paulo, Brazil) was used at a 1:100 dilution. The slides were analyzed under a fluorescence microscope. Intensity of fluorescence of the tachyzoite was considered as positive. The cut-off dilution was 1:50 for calves and dogs (Guimarães et al., 2004). Table 1 provides a summary of procedures and the corresponding tests carried out.

\section{Results and Discussion}

The summary of test results has been provided in Table 2. Samples from all the 14 cows were negative for IBR, $B V D$, neosporosis, and leptospirosis, and therefore, $N$. caninum was excluded as a potential etiologic agent at that juncture. Diagnostic screening is easy to perform, and the cows are expected to have high levels of antibodies against N. caninum when the abortion occurs. In any case, examination of the aborted fetuses is the best diagnostic approach. Sometimes, more than one fetus may need to be examined to increase the accuracy of the diagnosis (McAllister, 2016). Submission of an aborted fetus or its organs to a veterinary diagnostic laboratory may help in the early detection of the causative agent, and in adopting quick and necessary control measures, to avoid the spread of infection in the herd and to halt the abortions (McAllister, 2016). 
Table 1. Summary of animals, procedures and diagnostic methods from field and laboratory investigations

\begin{tabular}{|c|c|c|c|c|}
\hline Period & Animals & Procedures & Samples & Diagnostic methods \\
\hline December 2016 & 14 aborting cows & Blood samples & $\begin{array}{l}\text { Serology for IBR, BVD, } \\
\text { neosporosis and } \\
\text { leptospirosis }\end{array}$ & No data \\
\hline \multirow[t]{2}{*}{ March 2017} & $\begin{array}{c}\text { Aborted fetus } \\
\text { (approximately } 6 \text { months) }\end{array}$ & $\begin{array}{l}\text { Necropsy and blood } \\
\text { samples for serology }\end{array}$ & $\begin{array}{l}\text { Liver, spleen, thymus, } \\
\text { kidney, heart, skeletal } \\
\text { muscle, lung, and } \\
\text { central nervous system; } \\
\text { blood sample from } \\
\text { heart; and fluid samples } \\
\text { from thorax and } \\
\text { abdomen }\end{array}$ & Histology, PCR, and IFAT \\
\hline & Still born calf & $\begin{array}{l}\text { Necropsy and blood } \\
\text { samples from heart for } \\
\text { serology }\end{array}$ & Serology for N. caninum & IFAT \\
\hline \multirow[t]{2}{*}{ April 2017} & 340 cows and 146 heifers & Blood samples & $\begin{array}{c}\text { Serology for BVDV and } \\
\text { N. caninum }\end{array}$ & $\begin{array}{l}\text { Indirect ELISA (N. caninum) } \\
\text { and direct ELISA (BVDV) }\end{array}$ \\
\hline & Nine farm dogs & Blood samples & Serology for N. caninum & IFAT \\
\hline March-May 2017 & $\begin{array}{l}\text { Four aborted fetuses } \\
\text { of } 6,4 \text {, and } 5 \text { months, } \\
\text { approximately }\end{array}$ & $\begin{array}{l}\text { Blood samples from } \\
\text { heart }\end{array}$ & Serology for $N$. caninum & IFAT \\
\hline
\end{tabular}

IFAT - Indirect fluorescent antibody technique. ELISA - Enzyme-linked immunosorbent assay. BVDV - Bovine viral diarrhea virus. BVD - Bovine viral diarrhea. IBR - Infectious bovine rhinotracheitis.

Table 2. Summary of test results from the laboratory investigations.

\begin{tabular}{|c|c|c|}
\hline Animals & Diagnostic methods & Results \\
\hline 14 aborting cows & No data & $\begin{array}{c}\text { All animals were negative for } N \text {. caninum, } \\
\text { IBR, BVD, and Leptospira spp. }\end{array}$ \\
\hline Aborted fetus (approximately 6 months) & Histology, PCR, and IFAT & $\begin{array}{l}\text { Positive for } N \text {. caninum in PCR and IFAT. } \\
\text { Lesions in histopathological analysis are } \\
\text { suggestive of } N \text {. caninum infection. }\end{array}$ \\
\hline Stillborn calf & IFAT & Positive \\
\hline $\begin{array}{l}\text { Four aborted fetuses of approximately } 6 \text {, } \\
\qquad 5 \text {, and } 4 \text { months }\end{array}$ & IFAT & All fetuses were positive for $N$. caninum. \\
\hline & $\begin{array}{c}\text { Indirect ELISA (N. caninum) and direct } \\
\text { ELISA (BVDV) }\end{array}$ & 114 were positive (33.5\%) \\
\hline - 59 aborting cows & & - 44 were positive $(74.5 \%)$ \\
\hline 146 heifers & ELISA & 45 were positive (30.8\%) \\
\hline 9 farm dogs & IFAT & 5 were positive \\
\hline
\end{tabular}

IFAT - Indirect fluorescent antibody technique ELISA - Enzyme-linked immunosorbent assay. BVDV - Bovine viral diarrhea virus. BVD - Bovine viral diarrhea. IBR - Infectious bovine rhinotracheitis.

The local veterinarian requested our help in controlling the abortions, and in finding their root cause. We visited the farm in March 2017 to examine the cows, and found them in good general health. They did not show signs of any systemic disease or other clinical problem that may cause immunosuppression, and the consequent reactivation of a latent Neospora infection. The herd was vaccinated against important abortifacient infectious agents such as BVD, and Leptospira. All the 340 samples were negative for BVDV on direct ELISA. We found that the herd was managed well.

Neosporosis is the most difficult-to-control cause of cattle abortion because no vaccine or treatment is available, and in a closed herd it is difficult to prevent the abortions caused by the oocyst-contaminated water and feed, or due to the sylvatic cycle of the parasite (McAllister, 2016). This is a good example of how a closed herd can suffer an abortion storm. Maintaining the closed farm for more than three decades may increase the vulnerability of the herd 
to N. caninum, and the infection of naïve pregnant cows may start a wave of abortions among them (McAllister, 2016), while previously infected cows are more resistant to the horizontal transmission (Jenkins et al., 2000).

In the present farm, the corn silage was stored under tarpaulin, whereas the hay bales were stored in uncovered piles in an open-faced shed. The farm had 15 silos and corn silage stored for 2.5 years. Both corn silage and hay were produced in the farm, and dogs had access to silos and barns. Studies have demonstrated that abortion outbreaks can occur when susceptible cows are exposed to the pathogen through a common source, like contaminated feed (McAllister et al., 1996). The abortion storm was most probably caused by horizontal infection, and the source of infection was most likely to be hay or the contents of one of the 15 silos. How long the oocysts can persist in the environment, is not known (Lindsay \& Dubey, 2020). Contamination of food supplies may have happened at any time, since 5 of the 9 dogs were exposed to $N$. caninum. Alternatively, the stray and wild dogs may have contaminated the food storage, and be the source of infection, as they had access to the property. Discarding the fetal membranes, fetuses, offal, and dead animals in open, non-isolated places, was the common practice in the dairy farms in the neighborhood. Stray or wild dogs or even the farm's resident dogs might have consumed these carcasses, and later, contaminated the feed. Within a radius of $5 \mathrm{~km}$, there were at least 25 dairy farms with unknown status for Neospora.

The rates of abortions in 2013, 2014, and 2015 were $3.3 \%$ (8/243), 2.5\% (6/251), and 3\% (7/236), respectively. However, in 2016, it jumped to 17\% (42/250), and remained at 14.1\% (33/234), until April 2017. The mean gestational age of aborted fetuses was $5.75 \pm 1.08$ months. An abortion outbreak is declared when more than $10 \%$ of the vulnerable cows abort within a short time period (Lindsay \& Dubey, 2020). In the six states of Brazil, there are only sporadic reports of Neospora-associated abortions (Cerqueira-Cézar et al., 2017). This is probably the first description of an abortion storm associated with N. caninum, among the dairy cattle in Brazil.

In the present study, N. caninum antibodies were detected in 114 of 340 dairy cows and in 45 of 146 heifers by indirect ELISA. Almost 75\% of the aborting cows had antibodies against N. caninum (44/59), as expected (McAllister, 2016). However, serology does not provide information about the route of infection or its duration (Dubey et al., 2007). Therefore, we cannot completely rule out the transplacental route, as it is the major route of transmission in the cattle (Jenkins et al., 2000).

In the histopathology of the brain (Fetus 1) reported here, we observed random and diffuse foci of moderate to severe necrosis, surrounded by moderate lymphoplasmacytic inflammatory infiltration, characterized by multifocal non-suppurative encephalitis (Figure 1). Even though encephalitis is present in both BVDV and N. caninum infections, it is considered to be a characteristic of neosporosis (Pescador et al., 2007). The occurrence of lesions in the fetal brain is more evident, possibly because, it is the last organ to be affected by the protozoan, facilitating the diagnosis by brain analysis (Wouda et al., 1997). In this study, the etiologic agent was conclusively identified through PCR, as Neospora caninum (Fetus 1).

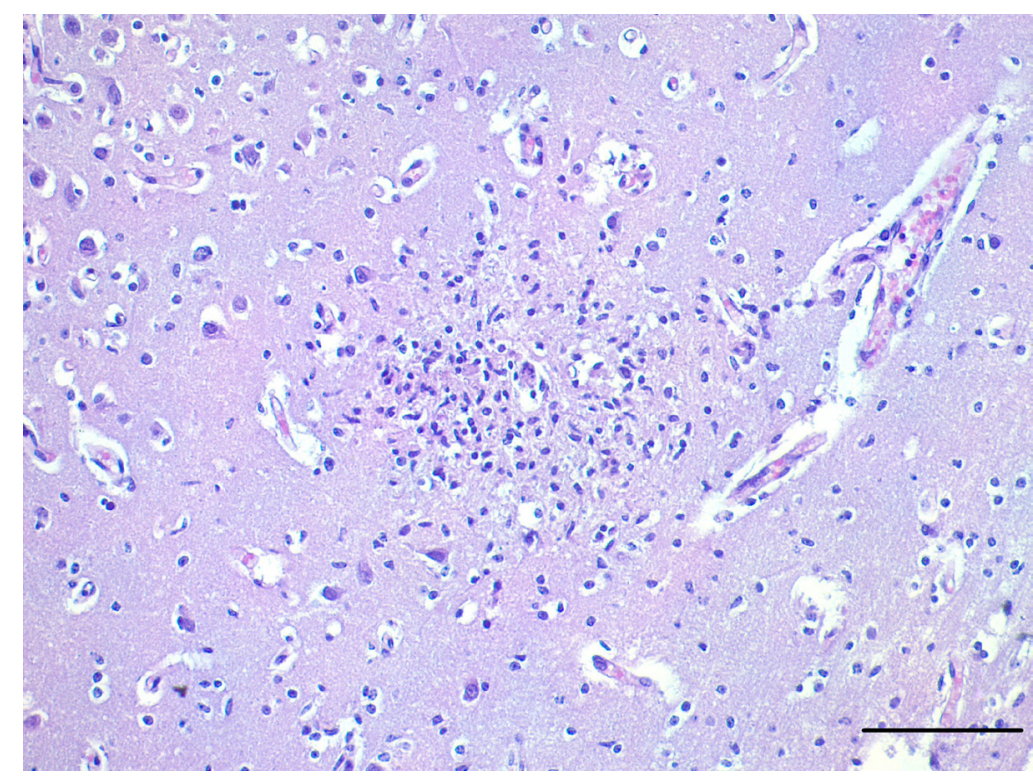

Figure 1. Photomicrography of brain from the aborted fetus. We observed a foci of moderate lymphoplasmacytic inflammatory infiltration, characterized by non-suppurative encephalitis. Hematoxylin and eosin stain, scale 200 $\mu \mathrm{m}$. 
Fetal heart showed the infiltrating mononuclear cells between the cardiac muscle bundles, and mild necrosis of cardiomyocytes, indicating a moderate multifocal lymphoplasmacytic myocarditis. The presence of mononuclear inflammatory infiltrates characterizes myocardial lesions, but the autolysis can mask it (Dubey \& Schares, 2006). However, myocarditis is not specific to neosporosis, but can also be due to BVDV infections (Pescador et al., 2007). Areas of multifocal and periportal random hepatocellular necrosis observed in the liver, indicated periportal hepatitis, as described previously in the neosporosis-associated abortions (Dubey \& Schares, 2006; Pescador et al., 2007). Multifocal hepatic necrosis was also described in BoHV-1-induced abortions; however, the lesions were both macro and microscopic (Anderson et al., 2012), unlike our findings.

Detecting $N$. caninum in bovine tissue using conventional histological analysis is challenging because the inoculum of parasites is generally low, and the lesions are not consistent with the presence of N. caninum (Dubey et al., 2006; Dubey \& Schares, 2006). Conversely, immunohistochemistry (IHC) is more reliable than the conventional histological approaches because it stains the tachyzoites and tissue cysts. This technique can be performed using all fetal tissues with lesions, but the parasite can be more frequently detected in the heart, lungs, and brain tissue (Dubey \& Schares, 2006; Pescador et al., 2007). Unfortunately, the examination of tissue samples of aborted fetus with IHC cannot be performed.

In summary, based on history, epidemiology, serological tests, and identification of the infective agent in the aborted fetuses, we were able to verify the exposure of this naive herd to $N$. caninum. Through histopathological analysis of tissues from an aborted fetus and PCR, we were able to identify $N$. caninum infection to be the most likely cause of abortions in this herd.

\section{References}

Almería S, López-Gatius F. Bovine neosporosis: clinical and practical aspects. Res Vet Sci 2013; 95(2): 303-309. http://dx.doi. org/10.1016/j.rvsc.2013.04.008. PMid:23659742.

Anderson M, Barr B, Rowe J, Conrad P. Neosporosis in dairy cattle.Jpn J Vet Res 2012; 60(Suppl.): 51-54. http://dx.doi.org/10.14943/ jjvr.60.suppl.s51. PMid:22458200.

Bjerkås I, Mohn SF, Presthus J. Unidentified cyst-forming Sporozoon causing encephalomyelitis and myositis in dogs. Z Parasitenkd 1984; 70(2): 271-274. http://dx.doi.org/10.1007/BF00942230. PMid:6426185.

Burg JL, Grover CM, Pouletty P, Boothroyd JC. Direct and sensitive detection of a pathogenic protozoan, Toxoplasma gondii, by polymerase chain reaction. J Clin Microbiol 1989; 27(8): 1787-1792. http://dx.doi.org/10.1128/JCM.27.8.1787-1792.1989. PMid:2768467.

Cerqueira-Cézar CK, Calero-Bernal R, Dubey JP, Gennari SM. All about neosporosis in Brazil. Rev Bras Parasitol Vet 2017; 26(3): 253-279. http://dx.doi.org/10.1590/s1984-29612017045. PMid:28876360.

Dubey JP, Schares G, Ortega-Mora LM. Epidemiology and control of neosporosis and Neospora caninum. Clin Microbiol Rev 2007; 20(2): 323-367. http://dx.doi.org/10.1128/CMR.00031-06. PMid:17428888.

Dubey JP, Buxton D, Wouda W. Pathogenesis of bovine neosporosis. J Comp Pathol 2006; 134(4): 267-289. http://dx.doi. org/10.1016/j.jcpa.2005.11.004. PMid:16712863.

Dubey JP, Schares G. Diagnosis of bovine neosporosis. Vet Parasitol 2006; 140(1-2): 1-34. http://dx.doi.org/10.1016/j. vetpar.2006.03.035. PMid:16730126.

Gondim LFP, MCAllister MM, Pitt WC, Zemlicka DE. Coyotes (Canis latrans) are definitive hosts of Neospora caninum. Int J Parasitol 2004; 34(2): 159-161. http://dx.doi.org/10.1016/j.ijpara.2004.01.001. PMid:15037103.

Guimarães JS Jr, Souza SLP, Bergamaschi DP, Gennari SM. Prevalence of Neospora caninum antibodies and factors associated with their presence in dairy cattle of the north of Paraná state, Brazil. Vet Parasito/ 2004; 124(1-2): 1-8. http://dx.doi.org/10.1016/j. vetpar.2004.07.002. PMid:15350656.

Jenkins MC, Caver JA, Björkman C, Anderson TC, Romand S, Vinyard B, et al. Serological investigation of an outbreak of Neospora caninum-associated abortion in a dairy herd in southeastern United States. Vet Parasitol 2000; 94(1-2): 17-26. http://dx.doi. org/10.1016/S0304-4017(00)00373-3. PMid:11078940.

Lindsay DS, Dubey JP, Duncan RB. Confirmation that the dog is a definitive host for Neospora caninum. Vet Parasitol 1999; 82(4): 327-333. http://dx.doi.org/10.1016/S0304-4017(99)00054-0. PMid:10384909.

Lindsay DS, Dubey JP. Neosporosis, Toxoplasmosis, and Sarcocystosis in Ruminants: an Update. Vet Clin North Am Food Anim Pract 2020; 36(1): 205-222. http://dx.doi.org/10.1016/j.cvfa.2019.11.004. PMid:32029185. 
Locatelli-Dittrich R, Dittrich JR, Richartz RRTB, Gasino Joineau ME, Antunes J, Pinckney RD, et al. Investigation of Neospora sp. and Toxoplasma gondii antibodies in mares and in precolostral foals from Parana State, Southern Brazil. Vet Parasito/ 2006; 135(3-4): 215-221. http://dx.doi.org/10.1016/j.vetpar.2005.10.010. PMid:16289863.

Locatelli-Dittrich R, Soccol VT, Richartz RRTB, Gasino-Joineau ME, Vinne R, Pinckney RD. Serological diagnosis of neosporosis in a herd of dairy cattle in southern Brazil.J Parasito/ 2001; 87(6): 1493-1494. http://dx.doi.org/10.1645/0022-3395(2001)087[1493:SD ONIA]2.0.CO;2. PMid:11780849.

McAllister MM, DubeyJP, Lindsay DS, Jolley WR, Wills RA, McGuire AM. Dogs are definitive hosts of Neospora caninum. Int J Parasitol 1998; 28(9): 1473-1479. http://dx.doi.org/10.1016/S0020-7519(98)00138-6. PMid:9770635.

McAllister MM, Huffman EM, Hietala SK, Conrad PA, Anderson ML, Salman MD. Evidence suggesting a point source exposure in an outbreak of bovine abortion due to neosporosis. J Vet Diagn Invest 1996; 8(3): 355-357. http://dx.doi. org/10.1177/104063879600800313. PMid:8844580.

McAllister MM. Diagnosis and Control of Bovine Neosporosis. Vet Clin North Am Food Anim Pract 2016; 32(2): 443-463. http:// dx.doi.org/10.1016/j.cvfa.2016.01.012. PMid:27161392.

Pescador CA, Corbellini LG, Oliveira EC, Raymundo DL, Driemeier D. Histopathological and immunohistochemical aspects of Neospora caninum diagnosis in bovine aborted fetuses. Vet Parasitol 2007; 150(1-2): 159-163. http://dx.doi.org/10.1016/j. vetpar.2007.08.028. PMid:17904290.

Pessoa GA, Martini AP, Trentin JM, Dalcin VC, Leonardi CEP, Vogel FSF, et al. Impact of spontaneous Neospora caninum infection on pregnancy loss and subsequent pregnancy in grazing lactating dairy cows. Theriogenology 2016; 85(3): 519-527. http://dx.doi. org/10.1016/j.theriogenology.2015.09.034. PMid:26542136.

Reichel MP, Ayanegui-Alcérreca MA, Gondim LFP, Ellis JT. What is the global economic impact of Neospora caninum in cattle The billion dollar question. Int J Parasito/ 2013; 43(2): 133-142. http://dx.doi.org/10.1016/j.ijpara.2012.10.022. PMid:23246675.

Reid AJ, Vermont SJ, Cotton JA, Harris D, Hill-Cawthorne GA, Könen-Waisman S, et al. Comparative genomics of the apicomplexan parasites Toxoplasma gondii and Neospora caninum: coccidia differing in host range and transmission strategy. PLoS Pathog 2012; 8(3): e1002567. http://dx.doi.org/10.1371/journal.ppat.1002567. PMid:22457617.

Santos APME, Navarro IT, Freire RL, Vidotto O, Bracarense APFRL. Neospora caninum em vacas leiteiras no Estado do Paraná, Brasil: análise histológica e imuno-histoquímica em fetos. Semina: Ciênc Agrár 2005; 26(4): 559-562. http://dx.doi.org/10.5433/16790359.2005v26n4p559.

Uesaka K, Koyama K, Horiuchi N, Kobayashi Y, Nishikawa Y, Inokuma H. A clinical case of neosporosis in a 4-week-old holstein friesian calf which developed hindlimb paresis postnatally. J Vet Med Sci 2018; 80(2): 280-283. http://dx.doi.org/10.1292/jvms.170205. PMid:29237996.

Wouda W, Moen AR, Visser IJR, van Knapen F. Bovine fetal neosporosis : a comparison of epizootic and sporadic abortion cases and different age classes with regard to lesion severity and immunohistochemical identification of organisms in brain, heart, and liver. J Vet Diagn Invest 1997; 9(2): 180-185. http://dx.doi.org/10.1177/104063879700900212. PMid:9211238. 